\title{
Prospects of Digital Financial Services in Bangladesh in the Context of Fourth Industrial Revolution
}

\section{Md. Harunur Rashid*}

Department of Public Administration and Governance Studies, Jatiya Kabi Kazi Nazrul Islam University (JKKNIU), Trishal, Mymensingh, Bangladesh.

*Correspondence: harun_du.rashid92@yahoo.com (Md. Harunur Rashid, Lecturer, Department of Public Administration and Governance Studies, JKKNIU, Trishal, Mymensingh, Bangladesh).

\section{ABSTRACT}

This paper attempts to reveal the prospects of Digital Financial Services (DFS) in Bangladesh with introducing associated concepts-fourth industrial revolution, digital economy, and digital financial services. Required data and information was collected primarily from the numerous sources of a secondary resource. It finds that Bangladesh has achieved remarkable progress in mobile phone penetration and secured among the top four countries advancing towards the digital economy rapidly. The country has tremendous prospects of DFS ahead; it will bring impressive economic growth and reduce poverty with huge strategic opportunities through connecting and using cutting edge technologies of the $4^{\text {th }}$ industrial revolution. Bangladesh government's effective policy reforms, digital Bangladesh's vision and a2i program ran by Prime Minister Office made this boom in spreading digital financial services. It was projected by Bangladesh Bank and Light Castle that the MFS trend will be grown consistently; there will be 407 million clients and BDT 121 billion will be transacted in 2022. Challenged IT infrastructures, few regulatory and operational constraints including digital illiteracy are considered as the barriers to using the full potentials of digital financial service. In realizing the goals of Sustainable Development Goals (SDGs), the article will be useful for policy-makers, academia, learners, policy advocates, experts, and stakeholders of digital financial services.

Keywords: DFS, MFS, Fourth Industrial Revolution (4IR), Digital Bangladesh, Financial services, and SDGs.

\section{INTRODUCTION:}

Industrial revolution transformed the society from feudal to high tech industrialized capitalist society, it witnessed four phase since the eighteenth century. It transformed the nature of job from physical activity to ever-changing creativity, allowed to release physical efforts into mental efforts (Prisecaru, 2016). First industrial revolution started with invention with steam engine in 1760 caused transition from farming and feudal society to manufacturing society, the develop-

UniversePG I www.universepg.com ment allowed train service for transportation as well as textile industry emerged. The invention of internal combustion engine in 1900 triggered second industrial revolution and it led rapid industrialization using oil and electricity. Third industrial revolution marked with development of electronics and information technology facilitated automatic production. The $4^{\text {th }}$ Industrial Revolution (4IR) is featured with using high biotechnology, three dimensional printing, robotics, computer generated product design with high speed (Xu et al., 2018). 
Information and Communication Technology (ICT) plays important role to implement the Sustainable Development Goals (SDGs), it is accelerating to achieve 17 goals of SDG within 2030. E-commerce and digital applications are promoting empowerment of women through creating entrepreneurs (Goal 5.b), creating decent job having with creativity and innovation through access to ICT enabled financial services (Goal 8.3). In achieving Goal 17.11, ecommerce is become increasing important to increase the exports of developing and Least Developed Countries (United Nation Conference on Trade and Development [UNCTAD], 2017). In 2016, Digital Economy represented $15.5 \%$ of global Gross Domestic Product (GDP), $18.4 \%$ in developed economies and $10 \%$ in developing economies, accounting $\$ 11.5$ trillion. The size of digital economy had grown two and half times faster than global GDP over the previous fifteen years and almost it was doubled since 2000 (UNCTAD, 2019).

According to Huawei Global Connectivity Index (GCI) 2019, Bangladesh is in top four countries in terms of development and growth of digital economy in the world. The report, based on 40 indicators, reveals that mobile subscription penetration jumped from 5 percent to 41 percent and smart phone penetration from 7 to 34 percent. This intelligent connectivity leads economic growth (Bangladesh among top four, 2019). DFS is mainly synonymous to Mobile Financial Service (MFS) in Bangladesh, mobile banking services especially Dutch Bangla Mobile Banking and bKash started the MFS. At least 18 banks and Non-Banks Financial Institution (NBFI) are operating MFS in Bangladesh covered 67 million people having with consistent growth; the average transaction is about BDT 316 billion as of December 2018. DFS is facilitating financial inclusion including rural people and leading technology adaptability among the people (Kibria, 2019).

The paper highlights the concept of $4^{\text {th }}$ Industrial Revolution (4IR), Digital Economy and DFS in first section. Secondly, the paper highlights the present scenario of DFS in Bangladesh. And finally the paper focuses on the prospects of booming DFS in Bangladesh.

\section{The Concept of $4^{\text {th }}$ Industrial Revolution (4IR):}

The term 'Fourth Industrial Revolution' coined in annual meeting of World Economic Forum (WEF) in 2016 at Davos by Professor Klaus Schwab, founder and Executive Chairman of the WEF, at first where connected technology with digital domains and offline reality will enable the human beings to manage their lives. The 4IR is building on the third industrial revolution that is characterized by fusion of technology and blurred the lines between the physical, digital and biological spheres. Speed, velocity, and system impact; these three key reasons marked 4IR distinctly compared to the third. The changes are occurring exponentially in 4IR rather than a linear pace (Xu et $a l .$, 2018). Schwab, (2016) explained 4IR in his book'The Fourth Industrial Revolution', published in January, 2016; in which he explained how way of living and work relating with one another are changing fundamentally. He delivered that the 4IR is basically distinct from the previous industrial revolution in which human being gained triumph on animal power and made huge progress on production. 4IR is characterized with new developed technologies; has impact on every discipline-physical, biological, and digital arena. 4IR has direct immense stakes in economics, industries, and on emerging ideas in years to come. The characteristics of 4IR are mobile devices possessed with unprecedented processing power, unlimited storage, and unlimited access to the knowledge; using Artificial Intelligence (AI), robotics, internet of things, autonomous vehicles, 3-D printing, nanotechnology, biotechnology, crypto currency, material science, energy storage and quantum computing. Usage of AI is already explicit in many fronts, driven by exponential increases of computing power (Schwab, 2016).

Prisecaro, (2016) mentioned Jeremy Rifkin's views on the features of 4IR - a). It would shift fossil fuel to renewable energy based production b). It will transform the building stock into green micro plant for collecting green energies from onsite c). It would use hydrogen and other sources of energies for intermittent energies d). It will use internet to transform the electricity network in every continent e. it will increase the use of electric and smart car through using green energy. 


\section{Concept of Digital economy:}

Digital economy or internet economy or web economy refers to the economic activity based on internet, digital computing technology and World Wide Web. It is underpinned by spread of Information and Communication Technology (ICT) in all businesses to increase productivity and it undermines the traditional business process. In 1990s, a Japanese professor and research economist mentioned the term 'Digital Economy' at first which was followed in the west and was coined in the book-'The Digital Economy: Promise and Peril in the Age of Networked Intelligence' by Don Tapscott in 1995. Thomas Mesenbourg mentioned three main components of Digital Economy in 2001 in his write up-Measuring Digital Economy. Three components are - 1). E-business infrastructure: It includes hardware, software, telecom, network and human capital; 2). Ebusiness: It indicates how business is conducted and the process of organization to operate business; and 3). E-commerce: It denotes transfer of goods channelized by online platforms (Digital Economy, Wikipedia).

Choi and Winston, (2000) defined the term that an economy which is characterized by computer and networking technology where market behaves differently under different rules from physical economy. Digital Economy is affiliated with network effects which are distinct from traditional business network, which reduces transaction costs, facilitates communication, building trusts, making authentication easy (Basu et al., 2020; Colin et al., 2015).

\section{The Digital Financial Service (DFS):}

Digital Financial Service (DFS) is affordable financial services which facilitate financial inclusion and reduce poverty. It is enabled by financial technology (Fintech), has lower costs, accuracy, speed, transparency and easier facility to reach rural poor people. Linda Kambale defined DFS that Digital Financial services include a broad range of financial servicespayments, savings, insurance, remittance, credit, etc. through accessed and delivered digital channels like internet, mobile phones, ATMs, POS terminal, etc.. DFS is also synonymous to the Mobile Phone Services (MFS). MFS is the use of mobile phone to get financial services introduced-M-banking, M-money, M-payment. World Bank Group Report - 2020 defines associated terms of DFS.

'Digital financial services (DFS) are financial services which rely on digital technologies for their delivery and use by consumers.

Fintech refers to digital technologies containing potential to transform the provision of financial services spurring the development of new - or modify existing-business models, applications, processes, and products. ${ }^{5}$ In practice, the term "fintech" is also broadly used to denote the ongoing wave of new DFS. Examples of these technologies include web, mobile, cloud services, machine learning, digital ID, and Application Programming Interfaces (APIs).

A Fintech firm is a new entrant in the financial sector that specializes in offering DFS. Examples of Fintechs include digital payment providers, digital insurers, digital-only banks, and peer-to-peer lending platforms.

A bigtech firm is a large company with an established technology platform and user base. Examples of bigtechs are online search engines, social media platforms, e-commerce platforms, hail-riding platforms, and mobile network operators. Leveraging technology and user network effects, several bigtechs launched to offer DFS.'

Source: World Bank Group 2020.

There are few proven models of DFS mentioned by World Bank Group report on Digital Financial Services-2020, include:

Mobile Money: In the model, financial services are rendered through mobile technology along with high phone penetration, this is also first wave of DFS model. Mobile phone is used to send money, cash in, UniversePG I www.universepg.com cash out, payments, and receive money without a formal bank account. M-Pesa in Kenya and bKash are the prominent example in this regard.

Platform Eco-systems Model: Bigtech platforms like social media, e-commerce, ride hailing, use this model and the model initiated another wave of DFS leveraging in large scale. Alibaba, and ride hailing 
service Gojek are the examples of this model, Cloud services and machine learning are used to generate customer date, and different apps are also used in this model.

\section{Open Application Programming Interfaces (APIs):}

It allows systems to exchange customer or citizen' data and information. To cover large number of customer or people, the model is applied. For example - Adhar biometric identification system in India which covers around 1 billion people. Bangladesh follows APIs to provide allowances to the target people under social security programs.

\section{State of Digital Financial Services (DFS) in Bangladesh:}

Bangladesh is moving fast in injecting digital operations in finance with innovation. Innovation in using mobile phone, introducing e-wallet, ATMs, POS, ebanking services and other DFS are playing effective role to reach the people especially to the poor people. Such digital products are not only fulfilling the financial needs but also creating new avenues to fulfill the future economic needs (Mujeri \& Azam, 2018). Digital Bangladesh is transforming the country regarded as important pillar of economy. The country graduated from lower income to lower middle income country, $34^{\text {th }}$ largest economy in the world with impressive economic growth in the last decade. The size of GDP is $\$ 250+$ billion and Bangladesh has impressive $80 \%$ mobile penetration. Bangladesh is experiencing technological leapfrog which has large tech savvy young generation and 12 million middle class people expected to triple in 2025 (Islam, 2018).

DFS allow user access to a number of financial services- utility payments, merchant payments, and banking services from anywhere and anytime. DFS has immense potential to facilitate formal channel of economic transaction as well as to increase financial inclusion with accuracy avoiding any fraudulent in a places where financial institutions are scarce (Shehab 2019). Bangladesh Bank, central bank of Bangladesh, issued guideline on 'Mobile Financial Services for Banks' in September 2011, it encouraged banks at first to introduce MFS. Later, the central bank encouraged the mobile phone operators and microfinance organizations to be an active partner in facilitating MFS in the country. Initially, 10 banks got license to operate MFS. bKash patronized by BRAC Bank and Dutch Bangla Bank Mobile Banking from Dutch Bangla Bank Limited (DBBL) were the two leaders in introducing MFS in Bangladesh (Chen, 2012).

After emergence of bKash, DFS in Bangladesh is synonymous to MFS, bKash filled vacuum of digital financial services in many ways. As of December 2018, 18 Banks and Non-Bank Financial Institution (NBFI) have license to operate DFS with 67 million users and it is progressing. The monthly average transaction is BDT 316 billion. Along with bkash, Dutch Bangla Rocket Mobile Banking has become second largest player in DFS patronized by DBBL where it has the largest ATM network throughout the country and has capability to DFS transaction. There have a couple of Payment Service Providers (PSPs), flourishing gradually, using mobile phone like-Upay, Pay360, and iPay. Around 28\% DFS transactions are being occurred in Over The Counter (OTC) through agents (Kibria, 2019). Kibria (2019) mentioned readiness indicators, Fig $\mathbf{1}$, of user group in Bangladesh which shows that $92 \%$ users have National Identification Number (NID) and others material to opening DFS account.

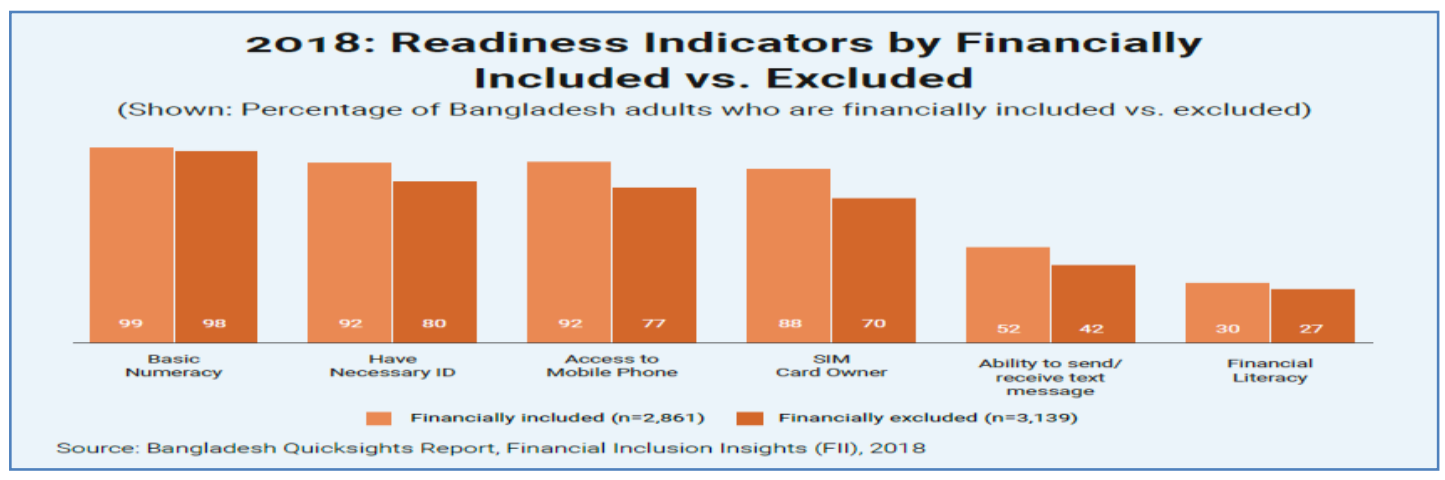

Fig 1: Readiness indicators to be financially included in Bangladesh. 


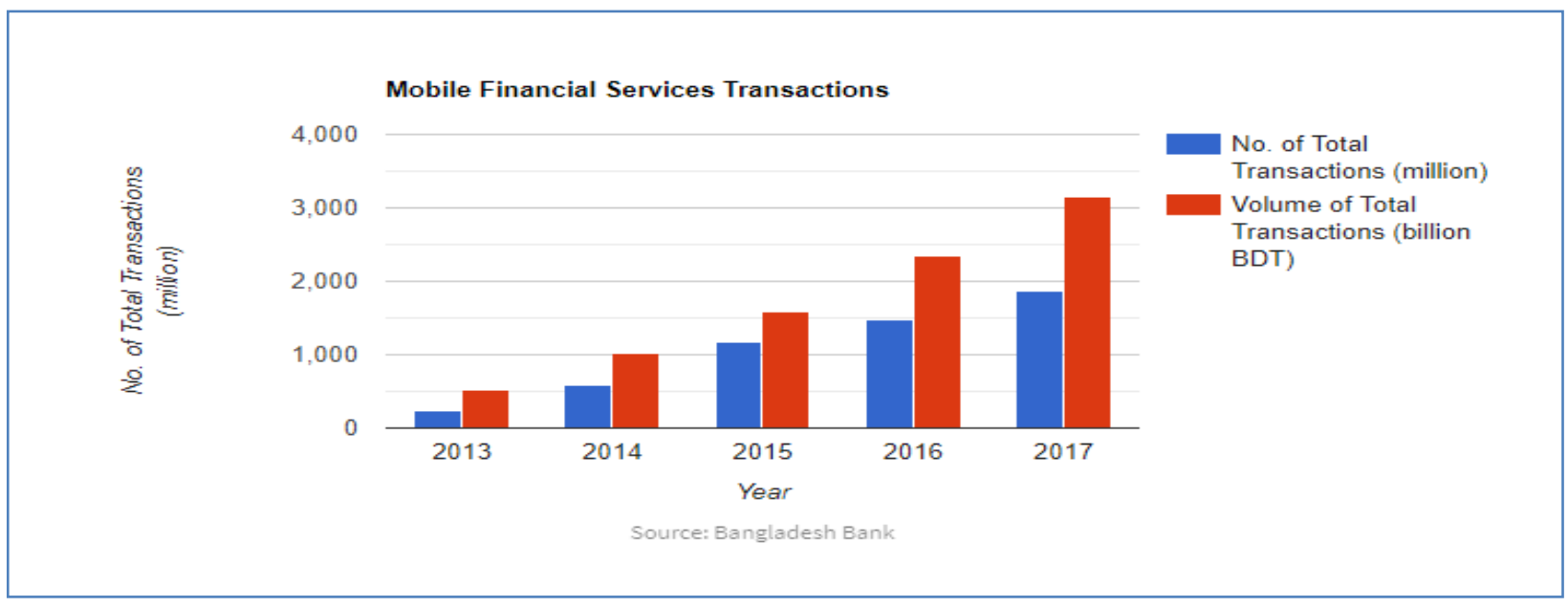

Fig 2: Mobile financial services transaction in Bangladesh.

DFS is being channelized by a number of MFS; Table 1 reveals key share holders who are shaping the market.

Table 1: Key Mobile Financial Services in Bangladesh.

\begin{tabular}{|c|c|c|c|}
\hline Service & Objective & Institutional Backing & Advantage \\
\hline iPay & Payment Platform & N/A & Digital Payment Focus \\
\hline Nagad & Digital Financial Service & Post Office & $\begin{array}{c}\text { Larger Transaction Limit; Regulatory } \\
\text { Advantage }\end{array}$ \\
\hline D Money & Digital Payment Platform & Post Office & $\begin{array}{c}\text { Digital Islamic Wallet } \\
\text { 2tk Accounts }\end{array}$ \\
\hline bKash & Mobile Financial Service & BRAC Bank & $\begin{array}{c}\text { Largest Market Share \& Network of } \\
\text { Agents }\end{array}$ \\
\hline Rocket & Mobile Banking & Dutch Bangla Bank & Banking Facilities \\
\hline Nexus Pay & $\begin{array}{c}\text { Mobile Financial Service for } \\
\text { Existing Customers }\end{array}$ & Dutch Bangla Bank & No Transaction Commission Charged \\
\hline
\end{tabular}

Source: Shehab, 2019.

887 thousands agents throughout the country are providing MFS services to the 67.52 million registered clients as of December 2018; of which 37.31 million are active accounts. Transaction is growing rapidly, now the daily transaction is BDT 10.36 billion, approximately \$ 123 million. These transactions are being taken place by banks, agents and clients; and it is making the country in top four countries in terms of MFS usage. In a month, average transaction stood BDT 316 billion (LigthCastle, 2019). According to 2017 report, $37 \%$ of the total population was included in full financial services institution which is $5 \%$ more from 2016; the picture shows an increase in financial inclusion through MFS (Shehab, 2019). Fig 2 shows the number of MFS transaction from 2013-2014.

iPay is a digital e-wallet which is connected to the user bank account and is recognized by over 100 brands including 2000 outlets. This service links all 57 banks of the country. Bangladesh's Post Office initiated Nagad, a digital financial service, covering 8500 branches. Nagad enjoys flexible regulation because it follows postal regulation instead of Bangladesh Bank regulations. It allows more than five times daily transaction. Fintech Company's product D Money is working with the Post Office aimed to reach the rural and remote areas. It initiates new service-'Daak Taka' which allow users to open an account costing BDT 2. Most popular MFS- bKash covers 60\% share covering nearly two lacks agents all over the country. It is providing a number of services-savings, cash in and out, payments, remittance services, etc. DBBL patronizes Rocket, a bank led MFS and first company offering banking facilities through mobile phone. Nexus Pay is app based financial services delivered by DBBL (Shehab, 2019). 


\section{Prospects of DFS in Bangladesh:}

According to Global Connectivity Index (GCI), Bangladesh is in leading four countries in terms of growth and remarkable achievement in Digital Economy. GCI reports that since 2015, Bangladesh advanced from $5 \%$ to $41 \%$ in mobile subscription penetration and boosted its score by $7 \%$ (Bangladesh among top four, 2019).

China Campus Network Bangladesh opined that access to information or a2i program, conducted by Prime Minister's office and supported by UNDP and USAID, is facilitating digital economy in Bangladesh. Government policy reform like-ICT policy, cyber security policy, mobile banking policy guideline, digital centers across the country, introducing national web portal and numerous policy support made this DFS boom in Bangladesh (Booming Digital Economy of Bangladesh, 2019). Bangladesh has been in a progressive move with adaptation of digital economy tools. Human resources development, people involvement, civil service and use of technology in businesses are four key elements of government to translate 'Digital Bangladesh Vision'. DFS has immense opportunity to include rest $53 \%$ unbanked population.

Fig 3 reveals the state of financial inclusion of Bangladesh. Micro Finance Institutions (MFI) covers around 32 million people giving $\$ 7.2$ billion annually. Large portion of poor is denied from institutional banking as $90 \%$ of 180 million poor household in Asia are out of institutional banking. MFI can be main way to include this group through digital channel-MFS (Hasnin, 2019).

Financial Inclusion in Bangladesh - 2018* (Shown: Percentage of Bangladesh Adults, $\mathrm{N}=6,000$ )

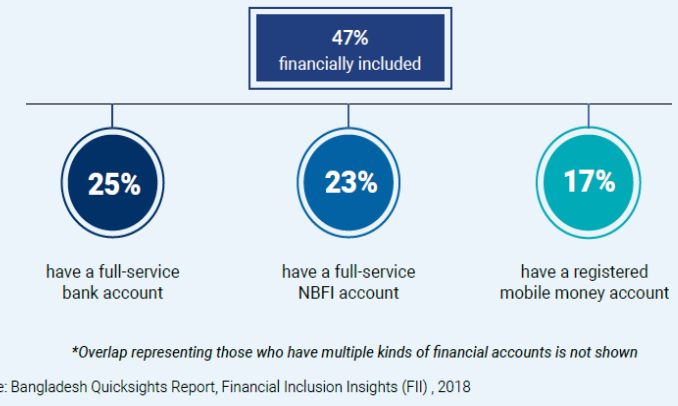

Fig 3: State of financial inclusion in Bangladesh.

UniversePG I www.universepg.com
Light Castle Partners produced a report in 2019 on 'The State of Digital Microfinance in Bangladesh' with support from Bill \& Melinda Gates Foundation. The report predicts the prospects of DFS in Bangladesh. According to Bangladesh Bank and LightCastle projections, the registered clients will be increased from 321.1 million in 2018 to 407.6 million in 2022 (Fig 4) while transactions through MFS will be reached from BDT 67.5 billion in 2018 to BDT 121.87 billion in 2022. MFS trend is forecasting consistent upward trend of use of MFS in Bangladesh.

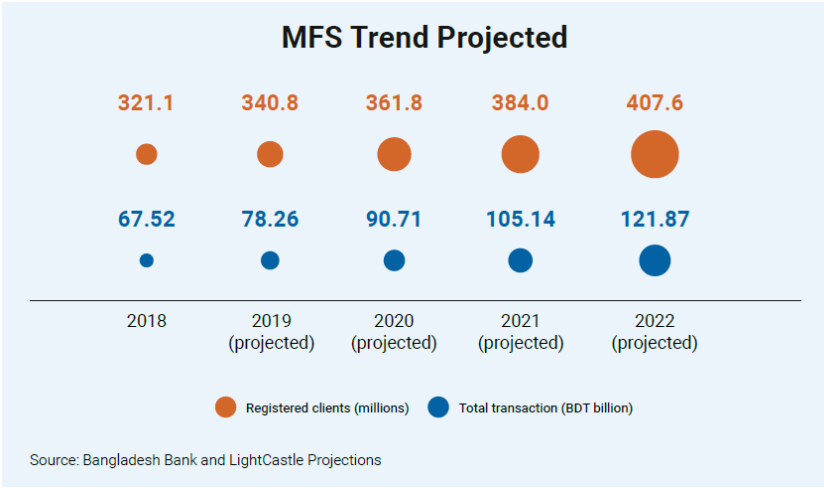

Fig 4: Projected MFS trend in Bangladesh.

Chakraborty, (2020) sees huge potentiality in widening DFS in Bangladesh as the country has seen rapid growth in digital economy. Intensive smart phone penetration, maturing support form young generation and enthusiastic entrepreneurs are gearing up the move towards digital economy. Educated people are getting accustomed to internet banking, digital payments using credit and debit card, mobile financial services, and ewallet. Shehab, (2019) observed that with present digital financial services, a large variety of DFS will be included in near future like- saving schemes, credit disbursements, insurance, and investing services. Hard cash transaction will decline; no matter what we think about future; there will be consistent boom in using DFS in Bangladesh.

For example that- amidst of corona virus pandemic, the use of MFS is increased greatly. The volume of leading MFS-bKash daily transaction in the pandemic is BDT 450 crores with 5.7 million transactions disclosing the density of digital transaction in the country (Daily 4.5 crores Transaction in bKash, 2020). Most recently, The Bank Asia is going to launch 'Digital Banking' in the coming December 2020. The entre- 
preneur is waiting for central bank approbation to initiate their services in full speed. This proposed digital bank will be connected to the National Payment Switch of Bangladesh where clients will be able to enjoy most of banking services from home instead of visiting bank physically. Bank Asia's Managing Director says the reason of introducing digital banking that-'Now, our new generation doesn't want to visit bank physically and they want to enjoy the banking services from home' (Sakib, 2020).

\section{CONCLUSION:}

Bangladesh has achieved remarkable progress in introducing digital economy through spreading digital financial services. Government's effective policy reforms and digital Bangladesh vision made this boom in financial technology industry. The country has huge prospects in DFS in years to come in the changed context due to fourth industrial revolution. Linking with 4IR tools- 5G network, Artificial Intelligence, internet of things and associated technological development will open up new horizon of opportunity in spreading DFS. Instead of immense progress towards building digital economy; nearly half of population remains unbanked and deprived from institutional financial services; DFS has opportunity to facilitate financial inclusion through MFS who are out of formal financial institutions especially to the rural and remote areas' people. Certainly, DFS will eradicate poverty from the bottom with opening new avenue of employment. Regulatory constraints- cash out limits, rigorous Know Your Customer (KYC) process, clients' incapacity-lack of digital literacy, management challenges, and operational challengesincreased transaction costs, lacking in IT infrastructure are crating barrier to unleash full advantages of DFS. If the regulatory authority and associated stakeholders come forward with transformational attitudes and meet the regulatory, management and operational challenges, the country will be able to use full potential of digital financial services.

\section{ACKNOWLEDGEMENTS:}

I would like to thank my lovely wife for her tireless support and courage to complete the article within timeframe. I am offering gratitude to my colleagues, Department of Public Administration and Governance UniversePG I www.universepg.com
Studies, Jatiya Kabi Kazi Nazrul Islam University, who inspired me incessantly to write on this issue.

\section{CONFLICTS OF INTEREST:}

It is being declared that there is no conflict of interest about the authorship and authenticity of this article.

\section{REFERENCES:}

1. Bangladesh among top four countries in digital economy growth, (2019). The Financial Express, November 20, viewed 13 July 2020. https://thefinancialexpress.com.bd/economy/ban gladesh/bangladesh-among-top-four-countriesin-digital-economy-growth-

2. Basu S, Roy A, and Karmokar S. (2020). Effectiveness of microfinance on household income generation strategy in the southwest region of Bangladesh, Asian J. Soc. Sci. Leg. Stud., 2(3), 56-62.

https://doi.org/10.34104/ajssls.020.056062

3. Booming Digital Economy of Bangladesh, (2019). China Campus Network Bangladesh, viewed 9 August 2020.

https://www.chinacampus.com.bd/news/boomin g-digital-economy-of-bangladesh/

4. Chakraborty, A. (2020). Digital Economy for a Digital Bangladesh, viewed 10 August 2020. http://www.fintechbd.com/digital-economy-fora-digital-bangladesh/

5. Chen, G. (2012). The Growth of Mobile Financial Services in Bangladesh [Blog post], viewed 14 August 2020. https://www.cgap.org/blog/growth-mobilefinancial-services-bangladesh

6. Choi, Y, S., \& Winston, B, A. (2000). The Future of Digital Economy. International Handbooks on Information System, Handbook on Electronic Commerce, pp. 25-52, https://link.springer.com/chapter/10.1007/978-3642-58327-8 2

7. Colin, N., Landier, A, Mohnen, P, \& Perrot, A. (2015). 'The Digital Economy', Conseil d'analyze economique, 26(7), pp. 1-12. https://www.cairn-int.info/journal-notes-duconseil-d-analyse-economique-2015-7-page$\underline{1 . h t m ? t r y \_d o w n l o a d=1}$ 
8. 'Daily 4.5 crores Transaction in bKash', (2020). The Daily Prothom Alo. March, 30, viewed 11 September 2020.

9. Digital Economy, (2020). Viewed 6 June 2020. https://en.wikipedia.org/wiki/Digital economy\#: $\sim:$ text=In\%202016\%2C\%20the\%20Digital\%20E conomy, in $\% 20 \mathrm{developing} \% 20 \mathrm{economies} \% 2 \mathrm{C} \%$ 20on\%20average

10. Hasnin, N. (2019). FinTech-Creating New Opportunities for MFIs in Bangladesh, viewed 22 July 2020.

https://databd.co/stories/fintech-creating-newopportunities-for-mfis-in-bangladesh-3401

11. Islam, B. (2018). Digital Financial Services: Expanding Role of Institutional Players, viewed 22 July 2020.

https://databd.co/stories/digital-financial-serviceexpanding-role-of-institutional-players-1229

12. Kibria, R. (2019). DFS in Bangladesh: Beyond Coffee Shops and Consumer Purchase, viewed 23 July 2020.

https://databd.co/stories/dfs-in-bangladesh-beyo nd-coffee-shops-and-consumer-purchase-2463

13. LigthCastle, (2019). The State of Digital Microfinance in Bangladesh, viewed 23 July 2020.

https://databd.co/wp-content/uploads/edd/2019/ 09/The-State-of-Digital-Microfinance-in-Bang ladesh.pdf

14. Mujeri, K, \& Azam, S. (2018). Role of Digital Financial Services in Promoting Inclusive Growth in Bangladesh: Challenges and Opportunities. Institute for Inclusive Finance and Development, Working Paper No. 55. http://inm.org.bd/wp-content/uploads/2018/06/ Working-Paper-55.pdf
15. Prisecaru, P. (2016). 'Challenges of the Fourth Industrial Revolution', Knowledge HorizonEconomics, 8(1), pp. 57-62.

16. Sakib, S. (2020). Bank Asia's Initiative: Coming New Digital Bank, The Daily Prothom Alo, August 24, viewed 24 August 2020.

17. Schwab, K. (2016). The Fourth Industrial Revolution: What it means, How to responds, World Economic Forum, 24 July 2020. https://www.weforum.org/agenda/2016/01/thefourth-industrial-revolution-what-it-means-andhow-to-respond/

18. Shehab, M. (2019). Digital Financial ServicesThe Next Step, viewed 25 July 2020. https://databd.co/stories/digital-financial-servic es-the-next-step-1398

19. United Nation Conference on Trade and Development, (2019). Digital Economy Report 2019, UNCTAD.

https://unctad.org/en/PublicationsLibrary/der201 9 overview en.pdf

20. United Nation Conference on Trade and Development, (2017), Maximizing the development gains from e-commerce and the digital economy, UNCTAD.

https://unctad.org/meetings/en/SessionalDocume nts/tdb_ede1d2_en.pdf

21. World Bank Group, (2020). Digital Financial Services, World Bank.

http://pubdocs.worldbank.org/en/230281588169 110691/Digital-Financial-Services.pdf

22. Xu, M, David, M, J \& Kim, H, S. (2018). 'The Fourth Industrial Revolution: Opportunities and Challenges'. International Journal of Financial Research, 8(1), pp. 90-95. https://doi.org/10.5430/ijfr.v9n2p90

Citation: Rashid MH. (2020). Prospects of digital financial services in Bangladesh in the context of fourth industrial revolution, Asian J. Soc. Sci. Leg. Stud., 2(5), 88-95. https://doi.org/10.34104/ajssls.020.088095 () 